\title{
Perception and Attitude of Students of Tertiary Institutions towards Entrepreneurship Eduction In Nigeria
}

\author{
Usman Y. Dutse*, Usman P. Mamaki**and Idrissa Djibo*** \\ Entrepreneurship Development Centre* \\ Federal Polytechnic, Bauchi*\& *** \\ Waziri Umaru Federal Poltyechnic, Birnin Kebbi**
}

\begin{abstract}
Entrepreneurship education in Nigeria was introduced into the schools curriculum with the aim of providing knowledge directed towards developing and inculcating into the students skills, competences, understanding and attributes that will equip them to be innovative, and to identify, create, initiate, and successfully manage personal, community, business and work opportunities. This study is on the perception and attitude of students in tertiary institutions towards entrepreneurial education in Nigeria schools. Questionnaire and interview were the instrument used and accidental sampling technique was adopted to select 300 respondents from two tertiary institutions of Abubakar Tafawa Balewa University, Bauchi and Federal Polytechnic Bauchi. Mean, rank order and t-test where the tools employed for the data analysis. It was found out that, majority of the respondents believes entrepreneurial education is a good policy and it has come to stay, they see it as a possible solution to the problem of high level unemployment, through self employment and job creation, source of revenue to government; will promote industrialization, innovation and technology. But they are of the opinion that the prospect of the programme will hardly be achieved due to poor policy implementation and other environmental factors. The t-test result show significant difference among respondents of different institution in their attitudes towards entrepreneurial education. Most student from the university are not keen and committed to entrepreneurship education because they see entrepreneurship as menial and risky, and their ambition is to seek for senior white-color job with certainty of income. While most of the polytechnic students are more committed to the programme which may be due to technical and vocational (TVE) training they undergo. Recommendation where made based on the findings of follows; there should be proper orientation and sensitization to students on the need for entrepreneurial education and practice in Nigeria, the course should not be made compulsory interested student should be made to register for it, government should be consistent and more committed towards policy implementation, Entrepreneurial support agencies should be repositioned and be more focused.
\end{abstract}

\section{Introduction}

In Nigeria like most African countries other developing nations, unemployment is a menace which has eaten deep into the nation's economy. The rate of employment is rapidly increasing due to increase in population, ineffective government policies, poor economic conditions, corruption etc. The disequilibria between the supply and demand for labor is likely to assume unmanageable proportions. Millions of educated and semi educated youths are roaming the streets without a gainful employment. The discontent and frustration among Nigeria youth is clearly reflected in youth different trends and pattern of restiveness of various dimension (Balogum, 2004).

In attempt to address the problem of unemployment and to promote economic growth and development, Nigerian government decides to adopt entrepreneurship as a panacea in appreciation of the experiences of other countries such as USA, Germany, Italy, Japan, China etc. Thus, entrepreneurial education was introduced to the curriculum of the Nigeria tertiary education (Ndububa, 2009).

According Aluwong, et al (2010) entrepreneurial education is a necessary ingredient for stimulating economic growth and employment opportunities in all societies. They further added that entrepreneurial education is a tool for fighting poverty and dependency; it has the perversity to continually provide business interest and skills to youth and also to;

- $\quad$ Provide more semi-skilled, skilled and professional manpower needed to revitalize, operate and sustain the economy.

- Help to reduce employment by providing and sustaining a generation of job creators rather jobs seekers.

- $\quad$ Promote creativity and innovation of the grass root

- $\quad$ Promote value addition and self reliance etc 
Entrepreneurship education is aimed at providing learning directed towards developing and inculcating into the students skills, competences, understanding and attributes that will equip them to be innovative, and to identify, create, initiate, and successfully manage personal, community, business and work opportunities (Momoh, 2008). The ability to actualize the objectives of entrepreneurial education to a large extent depends on the student's perception and attitudes towards the policy. This is because, the students' dedication and commitment depends on weather their perceptions and attitude towards the policy is positive or otherwise. Therefore, the paper aimed at studying the perception and attitudes of students of tertiary institutions towards entrepreneurship education in Nigeria. Abubakar Tafawa Balewa University, Bauchi and Federal Polytechnic, Bauchi are used for the study.

\section{Statement of Problem}

Nigeria is one of the countries in the world experiencing population growth without commensurate growth in the economy, as a growing economy it is clear that most Nigerians are saddled with poor economic conditions such as poverty, unemployment high dependency ration, and over dependence on government to provide jobs after graduation for the increasing number of youth.

The rate of youth employment is rapidly increasing; the Nigerian Tertiary Institutions have not contributed phenomenally towards managing that problem due to their inability to produce graduates that can be self employed and employers; thereby relying on government and the small private sector for employment. In an attempt to address that the Nigerian government introduces entrepreneurial education in the curricular of tertiary institutions with the aim of inculcating the spirit of entrepreneurship in the minds of students so that majority can effectively be self employed after graduation. The policy was received with mixed fillings like any other reform policy.

Therefore, the study aim of examine the perception and attitudes of students of tertiary institution towards entrepreneurial education in Nigeria. And also to ascertain whether there is significant differences between the students of universities and polytechnics in their attitudes and perception towards entrepreneurial education in Nigeria.

\section{Research Questions}

The questions the study seeks to address are as follows:-

i. How students of tertiary institution do perceive entrepreneurial education in Nigeria?

ii. Are there significant difference in the attitude and perception of students of universities and that of the polytechnics towards entrepreneurship education in Nigeria?

\section{Research Hypothesis}

$\mathrm{H}_{0}$ : There is no significant difference in the attitude of students of different

tertiary Institutions towards entrepreneurship education in Nigeria.

$\mathrm{H}_{1}$ : There is significant difference in the attitude of students of different tertiary

Institutions towards entrepreneurship education in Nigeria

\section{Research Methodology}

The data for the study were mostly primary obtained through the use of questionnaire and interview. Abubakar Tafawa Balewa University, Bauchi and Federal Polytechnic Bauchi, were used for the survey. A sample of 170 respondents where selected from the university and 130 from the polytechnic making the total of 300 respondents; Accidental sampling techniques was used for that purpose. The data collected were analyzed using mean and rank order and t-test.

\section{Data Presentation and Analysis}

The mean score of the items in the instrument were computed to determine the perception status of the respondents. A mean score of 2.50 and above $(X \geq 2.50)$ implies positive response to such item while a mean score below $2.50(\mathrm{X} \geq 2.50)$ implies negative response, as shown in the table below:-

Table 1: Showing the Mean and Rank Order of Respondents perception towards Entrepreneurial Education.

\begin{tabular}{|l|l|l|l|l|l|}
\hline S/N & Item No & Statement of Items & $\begin{array}{l}\text { Mean } \\
\text { Xesponse }\end{array}$ & Rank \\
\hline & & $\begin{array}{l}\text { In my views, entrepreneurial education at tertiary } \\
\text { initiative }\end{array}$ & $\cdot$ & & \\
\hline 1. & 1 & Is a good initiative & 3.50 & $1^{\text {st }}$ & Positive \\
\hline 2. & 2 & It should be encouraged & 3.48 & $2^{\text {nd }}$ & Positive \\
\hline 3. & 5 & Would reduce youth unemployment & 3.40 & $3^{\text {rd }}$ & $4^{\text {th }}$ \\
\hline 4. & 6 & $\begin{array}{l}\text { Would reduce over dependence you government } \\
\text { for job }\end{array}$ & 3.25 & $5^{\text {th }}$ & Positive \\
\hline 5. & 8 & Could help to raise the standard of living in & 3.20 & & Positive \\
\hline
\end{tabular}


Perception And Attitude Of Students Of Tertiary Institutions Towards Entrepreneurship

\begin{tabular}{|c|c|c|c|c|c|}
\hline & & magic & & & \\
\hline 6. & 7 & $\begin{array}{l}\text { it would inculcate in the youths sessile of } \\
\text { responsibility and belonging }\end{array}$ & 3.16 & $6^{\text {th }}$ & Positive \\
\hline 7. & 9 & It would enhance the innate talents of the youths & 3.12 & $7^{\text {th }}$ & Positive \\
\hline 8. & 12 & Would help to boost the Nigerian economy & 3.04 & $8^{\text {th }}$ & Positive \\
\hline 9. & 4 & It is the most preferred course in your curriculum & 2.52 & $9^{\text {th }}$ & Positive \\
\hline 10. & 10 & The objectives of entrepreneurial as targeted & 2.41 & $10^{\text {th }}$ & Negative \\
\hline 11. & 13 & $\begin{array}{l}\text { Could contribute significantly towards the } \\
\text { achievement of vision } 20: 20\end{array}$ & 2.25 & $11^{\text {th }}$ & Negative \\
\hline 12. & 11 & $\begin{array}{lll}\text { There is enabling environment } & \text { for } \\
\text { entrepreneurial development in Nigeria } & \end{array}$ & 2.18 & $12^{\text {th }}$ & Negative \\
\hline 13. & 3 & $\begin{array}{l}\text { The curricula for entrepreneurial education is } \\
\text { rich and comprehensive }\end{array}$ & 2.07 & $13^{\text {th }}$ & Negative \\
\hline
\end{tabular}

\section{T- Test}

Table 2: T- test Result of the Attitudes of students of Tertiary Institution toward Entrepreneurial Education in Nigeria.

\begin{tabular}{|l|l|l|l|l|l|l|}
\hline Tertiary institutions & No & Mean $(\mathrm{x})$ & Sd & df & t-cal & t-tab \\
\hline University & 170 & 3.28 & 31.24 & 289 & 2.1 & 1.96 \\
\hline Polytechnics & 130 & 2.20 & 24.80 & & & \\
\end{tabular}

Table 2 above shows the t-test of the attitude analysis of student's towards entrepreneurial education according to type of Institutions i.e Universities and polytechnics in Nigeria. The calculated t-value of 2.1 is greater than the table value of 1.96 indicating that there is significant difference between the attitude of university students and that of Polytechnic Students towards entrepreneurial education in Nigeria.

\section{Discussion of Findings}

The data in the table shows that perception of the majority of the student is positive towards entrepreneurial education. The respondents agreed positively to most of the items in favor of entrepreneurial education as shown, from items 1 to 9 in the table: The students opined that entrepreneurial education is a good initiative and should be encouraged in other to reduce youth unemployment and overdependence on government by graduates for jobs. They are also of the view that entrepreneurship education would increase the innate talent of the youth and inculcate into them the sense of belonging and responsibility thereby reducing youth's restiveness and insecurity in the country. In addition to that the respondents also see entrepreneurial education as a popular course in the curriculum because it is meant for all students.

On the other hand, there are negative perception on item 10 to 13; Most of the respondents of the opinion that the objectives behind the introduction of entrepreneurial education in Nigerians schools would not be achieved as expected and it cannot contributes significantly towards achieving vision 20:20:20. That believed is a result of lack of enabling environment for small scale entrepreneurs and to prosper in Nigeria and inconsistency in government policy implementation.

On the attitude of student of different tertiary institutions towards entrepreneurial education, the t-test analysis shows that there is significant difference between the students of university and polytechnics in their attitudes towards entrepreneurship education taught in their various institutions. The students from the university are indifferent in their attitude toward the course; they indifferent and less committed because they see it is a formality that they most pass through not something to use after graduation. Most of them prefer lucrative and white color job that would continuously bring large income periodically, rather then entrepreneurship that they see as menial, full of risk and uncertainty. This finding is line with the work of Okubanjo, (2009) who states that, university students are most likely to be aiming at higher lucrative jobs as most are children of the rich and big politicians.

On the part of the Polytechnic students are found to show more interest and commitment to entrepreneurial education. This may be due to the skill they acquire from the technical and vocational (TVE) training and practical activities they performed. Also their certificate of Ordinary National Diploma (OND) is for middle manpower and most of the students are from poor families. That concurs with the work of Chibuadu, (2011).

\section{Conclusion}

Based on the findings from the work, it therefore concludes that entrepreneurial education is a necessary instrument for promoting and effecting economic growth and development in Nigeria. It is evident that the objectives can only be achieve if there is proper implementation of the policy and the enabling environment is created for the graduates to exploit the opportunities available in the society. 


\section{Recommendations}

The following recommendations are made in line with the findings form the study:-

- There should be proper counseling and orientations of students on the imperatives and objectives of entrepreneurial education in tertiary institutions.

- Entrepreneurship courses should be elective rather than compulsory; so that only interested students will register for it, interest is always a motivator.

- Adequate funds and facilities should be provided for effective teaching learning.

- Regular train the trainer programmes should be organized periodically for the lecturers.

- Government should be consistent and committed towards the policy.

- Entrepreneurial support agencies should be repositioned and be more focused in other to provide the needed support to the interested students as they graduate.

\section{References}

[1]. Akunjobi, A.A (2002) Rudiment of Entrepreneurship Education for Universal Basic Education Vocational Renaissance. Vol. 1 No 1 Gonagol ventures, Kano

[2]. Aminu, H.M and Dutse, Y. U (2012) The Place of Entrepreneurial Education in Technical Education in Nigeria. A Paper presented at a conference of Nigeria Academy of Education $27^{\text {th }}$ Annual conference.

[3]. Balogun, M.D. (2004) Development of Entrepreneurial Potentials for Strategic Advantages: Nigerian Journal of Institute of Management $40(2,3$, x 4) pp $22-26$.

[4]. Chibuadu, E.E. (2011) Entrepreneurship and Economic Empowerment: Concepts, Attributes, Empowerment and Process. A Paper delivered at Federal Collage of Education (Technical), Akoka, at student Union week.

[5]. Hill, and Welsh H. (1986) Entrepreneurship Behavioufial Intentions and Students Independence Characteristics and Experiences.

[6]. Kenyon, J. (2002) Enterprise - Based Youth Employment Policies, Strategies and Programmes. Draft report to Ilo, Geneva.

[7]. Momoh, G. (2008). Business Education and Entrepreneurship. Bichi Journal of Business Education, Kano.

[8]. Ndububa, E.E. (2009) Introduction to Teachers Guide Paper presented at the in House capacity Building workshop for Academic staff on entrepreneurship education. Federal Polytechnic, Bauchi.

[9]. Olubadewo, S.O (2010) Global Economic Meltdown: Implications for Nigerian Education. African Journal of Academic Excellence pg. 1-10

[10]. Rae, D. (2008) Using a Life Story in Entrepreneurship Learning, the Development of Conceptual Model and its Implication in the Design learning Experiences, Education and Training. 42 (415), 220 - 227. 